\title{
Knowledge, Attitude and Practice Regarding Personal Protective Equipment During COVID-19 Pandemic Among Healthcare Workers in Hetauda
}

\author{
Susmita Bhattarai ${ }^{1}$, Srijana Pradhan ${ }^{2}$ \\ 'Nepal Institute of Health Sciences, Jorpati, Kathmandu, Nepal; \\ ${ }^{2}$ Department of Medical Surgical Nursing, Nepal Institute of Health Sciences, Jorpati, Kathmandu, Nepal.
}

Introduction: Personal protective equipment (PPE) is one of the effective measures to protect health care workers while caring confirmed or suspected patients with COVID-19.

Objective: To assess the knowledge, attitude, and practice regarding the use of PPE among healthcare workers (HCWs) in Hetauda during COVID-19 pandemic.

Methods: A descriptive cross-sectional study was conducted among $138 \mathrm{HCWs}$ from three hospitals in Hetauda: Hetauda Hospital, Makwanpur Sahakari hospital and Hetauda Orthopedic Hospital between December 2020 and January 2021 for two weeks. A validated self-administered questionnaire, Likert scale and Observational checklist were used for data collection. The simple descriptive statistics (percentage, mean) and inferential statistics (Chi-square test) were used for the data analysis.

Results: The findings of the study showed that the mean age of the respondents was 26.54 years. Half of the total respondents $70(50.7 \%)$ had adequate knowledge, half $69(50 \%)$ had positive attitude and more than half of the respondents had poor practice $60(60 \%)$ regarding the use of PPE during COVID-19 pandemic. There was significant association of knowledge regarding the use of PPE with training, continue education, profession and attitude at $\mathrm{p}<0.05$ level of significance.

Conclusion: This study concludes that the periodic training program for newly recruited HCWs and refresher training/ continue education for old HCWs to update about the proper use of PPE would enhance the knowledge, attitude and practice of the HCWs. The hospitals should follow the standard PPE guidelines by CDC or WHO while donning and doffing the PPE during the care of Covid patients.

Keywords: Attitude; covid-19; knowledge; pandemic; personal protective equipment; practice.

\section{INTRODUCTION}

COVID-19 is a rapidly expanding global pandemic caused by a novel human corona virus (SARS-COV-2). ${ }^{1}$ Health care workers (HCWs) are the frontline workers during pandemic who are at great risk of Covid-19 transmission and death. According to International council of Nurses (ICN), at least 90,00o HCWs were infected by COVID-19 and more than 260 nurses had succumbed to the disease. ${ }^{2}$

Current evidence suggests that the Corona virus is transmitted between people through close contact and droplets. ${ }^{3}$ PPE provides a physical barrier between virus and the HCWs. It is important to reduce risk and make the workplace safe for both the patients and health care workers. ${ }^{4}$

A cross sectional study conducted to assess the knowledge, attitude, and practice regarding PPE among 393 HCWs for the prevention of COVID-19 in Bangladesh

Citation: Bhattarai S, Pradhan S. Knowledge, attitude and practice regarding personal protective equipment during COVID-19 pandemic among healthcare workers in hetauda. Nepal J Health Sci. 2021 Jan-Jun;1(1): 48-56 
in Feb, 2021 showed that there was good knowledge, positive attitude and poor practice. ${ }^{5}$ Various global studies show that there are significant gaps in the area of practice regarding PPE. ${ }^{5,20}$ Since the pandemic hit Nepal, many HCWs were infected while some were succumbed. ${ }^{6}$ Therefore, the researcher felt it necessary to assess the knowledge, attitude and practice regarding the use of PPE among the HCWs in Hetauda during COVID-19 pandemic.

\section{MeThodS}

This was a descriptive cross sectional study. This study was conducted at three different hospitals in Hetauda District (i.e. Hetauda hospital, Makwanpur Sahakari Hospital and Hetauda Orthopedic Hospital). Hetauda hospital was working as a referral center for the treatment of COVID-19 patients with the facility of COVID-19 isolation wards. The data collection was started from the last week of December 2020 to the first week of January 2021.

The study population was all the healthcare workers of the three hospitals in Hetauda at the time of data collection. Knowledge and attitude of the health care workers was assessed from all the departments of three hospitals through questionnaires while practice was observed only in the COVID-19 isolation ward of Hetauda hospital. The sample size was 138 and convenient sampling technique was used to select the sample. The areas were selected purposively. A semi- structured questionnaire was applied to collect socio-demographic information and assess the knowledge while Likert scale was used to measure attitude towards the use of PPE. An observational checklist was used to assess practice regarding the use of PPE (donning and doffing PPE) among 10\% of healthcare workers working in the COVID-19 isolation ward of Hetauda Hospital.

The tool was prepared through an extensive review of literature, WHO and CDC guideline ${ }^{7,8}$ and with the help of research advisor. Validity of the instrument was maintained by calculating the content validity index (CVI) which was obtained (o.9). The research instrument was sent to two professors of nursing department of the same institute for its content validation. A small scale pilot study was conducted by pre-testing $10 \%$ of the study population of similar group at Sancho hospital in Hetauda for feasibility testing, where or and is suitable the number of items related to the knowledge was reduced due to its repetition.

The study comprised question evaluating socio demographic variables, knowledge, attitude and practice regarding the use of PPE. Socio demographic information included age, gender, educational qualification, profession, working hour, working experience, working area, continue education on COVID-19 and training on use of PPE. The knowledge section included twenty five questions including multiple responses. The correct response was provided ' 1 ' mark and incorrect ' 0 ' mark. The total highest score was 24 out of 25 where mean score was (17.04). The mean knowledge score was used to categorize adequate knowledge (ie. above mean) and inadequate knowledge (ie. below mean). ${ }^{9}$

Similarly, the attitude section consisted eleven items and responses of each item were documented on a 5-point Likert scale as follows: strongly agree (5-point), agree (4-point), undecided (3-point), disagree (2-point), and strongly disagree (1-point). Total highest attitude score was 51 out of 55 where mean score was (40.87). The mean attitude score was used to assess positive attitude (i.e. above mean) and negative attitude (i.e. below mean). ${ }^{9}$

An observation checklist was used to assess the practice (ie Donning and doffing PPE according to WHO guideline). ${ }^{7}$ The practice section consisted 20 items and each item comprised two responses: Yes (1-point) and No (o-point). The respondents performing complete donning and doffing PPE were indicated good practice while respondents performing incomplete donning and doffing PPE were indicated poor practice. The practice of donning and doffing PPE was observed by the researcher wearing all the necessary PPE kits at the time of their duty exchange in the morning and evening shift for three days without having them knowing that they were being observed.

The collected data was entered into EPI-Data version 3.1 and analyzed through Statistical Package for Social Sciences (SPSS) version 16.0 software. The data was interpreted based on objectives of the study by using 
simple descriptive statistics such as frequency, mean, percentage and presented in the table while the inferential statistics such as Chi-square test was used to find the association between the demographic variables at 95\% confidence level ( $p$-value < 0.05)

The ethical approval was obtained from the Institutional Review Committee (IRC) of Nepal Institute of Health Sciences (NIHS), Purbanchal University, Gokarneshwor-5, Jorpati, Kathmandu (Ref No. 01/77). Written permission was taken from all the three hospitals (Hetauda hospital, Makwanpur Sahakari Hospital and Hetauda Orthopedic Hospital).
Informed verbal and written consent was taken from each respondent after explaining the objective of the study before the study commencement. The participation in the study was voluntary. They had the right to ask question and they could withdraw from the study at any time without having to give any reason. The privacy and confidentiality of the data was maintained by using respondent codes to label the data instead of using their names and securing the data by encryption of folders. The information collected was utilized only for this study.

\section{RESUlTS}

Table 1: Demographic characteristics of the respondents

\begin{tabular}{|c|c|c|c|}
\hline \multicolumn{2}{|c|}{ Variables name with category } & $\begin{array}{c}\text { Frequency } \\
\text { (f) }\end{array}$ & Percentage \\
\hline \multirow{2}{*}{ Age(in completed years) } & Below 30 years & 108 & 78.3 \\
\hline & Above 30 years & 30 & 21.7 \\
\hline \multirow{2}{*}{ Gender } & Male & 36 & 26.1 \\
\hline & Female & 102 & 73.9 \\
\hline \multirow{8}{*}{ Profession } & Doctor & 12 & 8.7 \\
\hline & Nurse & 69 & 50 \\
\hline & Health assistant & 14 & 10.1 \\
\hline & Lab technician & 17 & 12.3 \\
\hline & CMA & 1 & 0.7 \\
\hline & ANM & 11 & 8.0 \\
\hline & Radiographer & 5 & 3.6 \\
\hline & Pharmacist & 9 & 6.5 \\
\hline \multirow{9}{*}{ Working Area } & Emergency & 26 & 18.8 \\
\hline & General ward (Medical and surgical) & 41 & 29.7 \\
\hline & $\mathrm{ICU} / \mathrm{CCU}$ & 18 & 29.7 \\
\hline & Operation theater & 15 & 13.0 \\
\hline & Post-operative ward & 7 & 10.9 \\
\hline & Covid isolation ward & 10 & 5.1 \\
\hline & Lab & 7 & 7.2 \\
\hline & Radiology unit & 5 & 5.1 \\
\hline & Pharmacy & 9 & 3.6 \\
\hline \multirow{2}{*}{ Working hour } & 6 to 7 hours & 120 & 87 \\
\hline & 8 to 9 hours & 18 & 13 \\
\hline \multirow{4}{*}{ Working experience } & Less than 1 year & 37 & 26.8 \\
\hline & 1 to 5 year & 78 & 56.5 \\
\hline & 6 to 10 year & 9 & 6.5 \\
\hline & More than 10year & 14 & 10.2 \\
\hline \multirow{4}{*}{ Educational qualification } & Master's degree & 8 & 5.8 \\
\hline & Bachelor degree & 42 & 30.4 \\
\hline & Diploma & 75 & $54 \cdot 3$ \\
\hline & Pre- diploma & 13 & 9.4 \\
\hline
\end{tabular}


Table 1 shows that the mean age of the respondents was 26.54 years while maximum and minimum age was 56 years and 18 years respectively. Majority of the respondents 102 (73.9\%) were female. Similarly, majority of the respondents 69 (50\%) were Nurses, 12 (8.7\%) were Doctors, 14 (10.1\%) were Health Assistant followed by others. Majority of the respondents 41
(29.7\%) were working in General ward, 10 (7.2\%) in Covid isolation ward. The mean working hour was 6.62 hours. The mean working experience was 4.16 years while the minimum working experience was 0.3 years and maximum 32 years. Similarly, majority of the respondents 75 (54.3\%) had Diploma level of educational qualification.

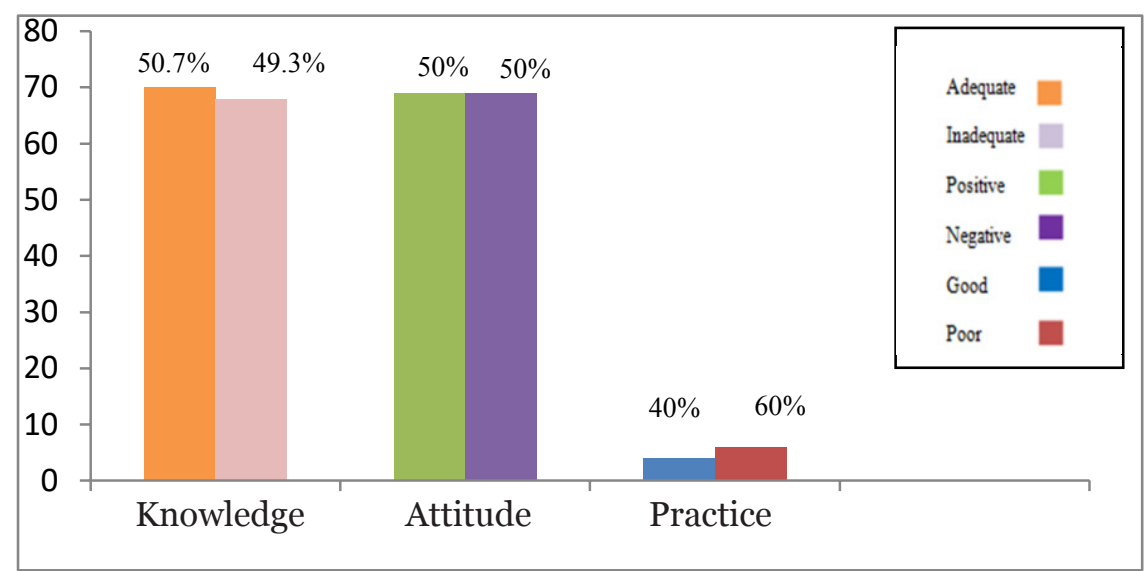

Figure 1: Distribution of respondents based on knowledge, attitude and practice

Figure 1 reveals that among total respondents, nearly more than half of the respondents 70 (50.7\%) had adequate knowledge meanwhile nearly half 68 (49.3\%) had inadequate knowledge regarding the use of PPE during COVID-19 pandemic. Similarly, half of respondents 69 (50\%) had positive attitude whereas half $69(50 \%)$ had negative attitude towards the use of PPE during COVID-19 pandemic. Upon observing 10 respondents working in Covid isolation ward, less than half of respondents 4 (40\%) had good practice and more than half 6 (60\%) had poor practice regarding the use of PPE during COVID-19 pandemic.

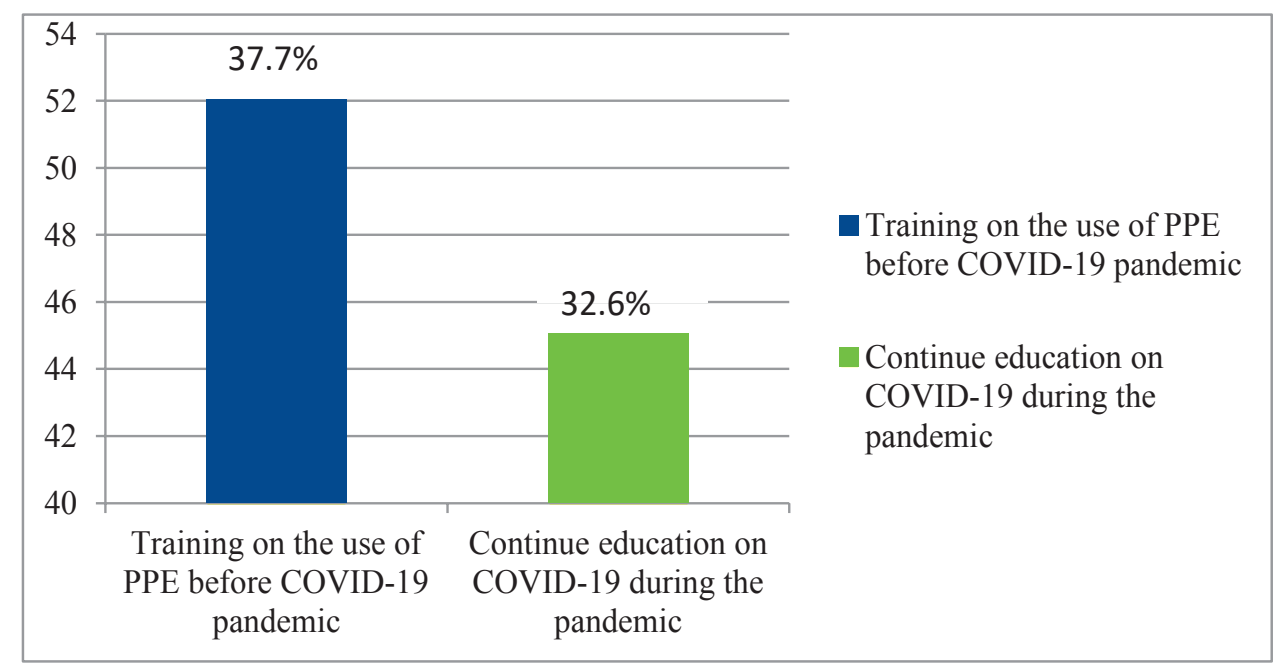

Figure 2: Distribution of respondents based on training/ continue education received

Figure 2 reveals that among total respondents, less than half of the respondents 52 (37.7\%) had received training on the use of PPE before COVID-19 pandemic with the purpose of infection prevention and control measure. Similarly, less than half of the respondents 42 (32.6\%) had received in-service education on COVID19 during COVID-19 pandemic. 


\section{Definition of PPE}

Physical barriers between wearer and microorganism

Special equipment used to reduce the chance of touching, being exposed to and spreading germs to other HCWs and patients

\section{Purpose of wearing PPE during COVID19 pandemic*}

Prevent the spread of corona virus transmission

Protect healthcare workers from contamination

\section{Device included as PPE during COVID19 pandemic*}

Gloves

Gown

Mask

Goggles and face shield

Boots

\section{Benefit of using PPE during COVID19 pandemic*}

Prevents spread of corona virus

Protect healthcare workers and patients from Covid infection

Disadvantage of using PPE during COVID19 pandemic*

Irritation / Allergy

Discomfort, suffocation and over heating

Time consuming

Decreases in the field of vision or reductions in manual dexterity

\section{Factors affecting PPE usage in Hospitals *}

Unavailability of PPE

\section{Heard about donning and doffing**}

Yes

\section{Meaning of donning and doffing PPE $\quad(n=95)$}

Sequence of putting on and taking off/removing PPE

Technique of wearing PPE

Standard technique regarding PPE

Importance of proper donning and doffing PPE*

To avoid the transmission of corona virus to the HCWs

\section{Correct order of donning PPE}

Perform hand hygiene, Put on gown, Put on face mask, Put on face shield/eye protection,

Put on gloves

\section{Correct order for doffing PPE}

Remove gloves, Remove gown, Perform hand hygiene/ hand sanitizer, Remove face shield/ eye protection, Remove mask, Perform hand hygiene, Remove shoe covers

\section{Discarding PPE}

Separate waste container (Biohazard plastic wrapped dustbin)

Effective strategies for sustaining PPE use throughout COVID -19 pandemic* $(n=138)$

Government and hospital should formulate policies and actions

Assessment and evaluation of the knowledge and performance of HCWs about PPE use

Training programs should be arranged for newly recruited staffs and refresher training for old staffs related to PPE use during COVID - 19 pandemic

\begin{tabular}{|c|c|}
\hline 54 & 39.1 \\
\hline 103 & 74.6 \\
\hline 113 & 81.88 \\
\hline 86 & 62.31 \\
\hline 138 & 100.0 \\
\hline 138 & 100.0 \\
\hline 138 & 100.0 \\
\hline 138 & 100.0 \\
\hline 138 & 100.0 \\
\hline 118 & 37.7 \\
\hline 133 & 42.1 \\
\hline 72 & 52.17 \\
\hline 121 & 87.68 \\
\hline 59 & 42.75 \\
\hline 34 & 24.63 \\
\hline 117 & 84.78 \\
\hline 95 & 68.8 \\
\hline 86 & 90.5 \\
\hline 6 & 6.3 \\
\hline 3 & 3.2 \\
\hline 95 & 100.0 \\
\hline 59 & 64.8 \\
\hline 59 & 62.1 \\
\hline 95 & 100.0 \\
\hline 69 & 50 \\
\hline 81 & 58.7 \\
\hline 121 & 87.7 \\
\hline
\end{tabular}

[Note: $\left({ }^{*}\right)$ refers to Multiple Responses, $\left({ }^{* *}\right)$ means this item was not included in knowledge] 
Table 2 shows that majority of the respondents 103 (74.6\%) responded PPE as special equipment used to reduce the chance of touching, being exposed to and spreading germs to other HCWs and patients. Majority of the respondents 113 (81.88\%) responded that the purpose of wearing PPE during COVID-19 pandemic was to prevent the spread of corona virus transmission. All the respondents 138 (100\%) responded that PPE includes Gloves, Gown, Mask / respirator, Goggles and face shield and Boots. Similarly, majority of the respondents 133 (96.37\%) responded that PPE protects healthcare workers and patients from Covid infection. Majority of the respondents 121 (87.68\%) responded that wearing PPE for whole duty hour makes them discomfort, suffocation and overheating. Similarly, majority of the respondents 117 (84.78\%) responded that unavailability of PPE affects the proper use of the PPE in the hospital.

Similarly, more than half of the respondents 95 (68.8\%) had heard about donning and doffing PPE. Hence, out of 95 respondents, majority of them 86
(90.5\%) responded that the meaning of donning and doffing was a sequence of putting on and taking off PPE. All the respondents 95 (100\%) responded the importance of proper donning and doffing is to avoid the transmission of corona virus to the HCWs. More than half of the respondents 77 (55.8\%) responded that a trained observer or a colleague is needed while donning and doffing PPE in order to prevent from PPE contamination. Less than half of the respondents 59 (62.1\%) responded the correct order of donning and doffing PPE while remaining respondents responded the incorrect order of donning and doffing PPE. All the respondents 95 (100\%) responded that the PPE should be discarded in a separate waste container. Regarding effective strategies for sustaining PPE use throughout COVID-19 pandemic, majority of the respondents $121(87.7 \%)$ responded that training programs should be arranged for newly recruited staffs and refresher training for old staffs related to PPE use during COVID-19 pandemic while 69 (50\%) responded on hospital should follow standard PPE guideline.

Table 3 Association of knowledge and attitude with selected demographic variables

\begin{tabular}{|c|c|c|c|c|c|}
\hline Dependent variable & $\begin{array}{c}\text { Independent } \\
\text { variable }\end{array}$ & $\begin{array}{c}\text { Chi- square } \\
\text { (x2) }\end{array}$ & $\begin{array}{l}\text { Degree of } \\
\text { freedom }\end{array}$ & P value & Association \\
\hline $\begin{array}{l}\text { Knowledge regarding } \\
\text { the use of PPE }\end{array}$ & $\begin{array}{c}\text { Continue education } \\
\text { on COVID-19 }\end{array}$ & 16.472 & 1 & $<0.001$ & Yes \\
\hline $\begin{array}{l}\text { Knowledge regarding } \\
\text { the use of PPE }\end{array}$ & $\begin{array}{c}\text { Training on use of } \\
\text { PPE }\end{array}$ & 13.933 & 1 & $<0.001$ & Yes \\
\hline $\begin{array}{l}\text { Knowledge regarding } \\
\text { the use of PPE }\end{array}$ & Profession & 8.814 & 1 & 0.003 & Yes \\
\hline $\begin{array}{l}\text { Knowledge regarding } \\
\text { the use of PPE }\end{array}$ & $\begin{array}{c}\text { Attitude towards use } \\
\text { of PPE }\end{array}$ & 7.422 & 1 & 0.006 & Yes \\
\hline $\begin{array}{c}\text { Attitude towards use } \\
\text { of PPE }\end{array}$ & $\begin{array}{c}\text { Continue education } \\
\text { on COVID-19 }\end{array}$ & 0.297 & 1 & 0.586 & No \\
\hline $\begin{array}{c}\text { Attitude towards use } \\
\text { of PPE }\end{array}$ & $\begin{array}{c}\text { Training on use of } \\
\text { PPE }\end{array}$ & 0.000 & 1 & 1.000 & No \\
\hline $\begin{array}{c}\text { Attitude towards use } \\
\text { of PPE }\end{array}$ & Profession & 0.365 & 1 & 0.546 & No \\
\hline
\end{tabular}

Table 3 indicates that there was significant association between knowledge regarding the use of PPE and continue education $(\mathrm{p}=<0.001)$, training $(\mathrm{p}=<0.001)$ and profession $(\mathrm{p}=0.003)$. Similarly, there was also significant statistical association between knowledge and attitude towards the use of PPE during COVID-19 pandemic ( $\mathrm{p}=0.006$ ). However, there was no significant association of attitude of health care workers with continue education, training and their profession at $<0.05$ level of significance. 


\section{DisCUSSIONS}

In this study, it was found that more than half of the respondents 86 (62.3\%) had not received training on the use of PPE during or before COVID-19 pandemic while less than half of the respondents $52(37.7 \%)$ had received training on the use of PPE before COVID-19 pandemic with the purpose of infection prevention and control measure. A similar result was found in a cross sectional study conducted among 600 health care workers at El-Demerdash Hospital, a teaching hospital in Cairo, Egypt in august 2020 which showed that most of the healthcare workers 353 (58.8\%) did not receive any training on the importance of PPE. ${ }^{7}$

In this study, it was found that half of the respondents 70 (50.7\%)had adequate knowledge regarding the use of PPE. A similar result was found in a cross sectional study conducted among 393 healthcare workers from five different districts of Bangladesh revealed that most of the healthcare workers 391 (99.5\%) had good knowledge regarding personal protective equipment. ${ }^{5}$

Similarly, in this study, it was found that only half of the respondents 69 (50\%) had positive attitude towards the use of PPE among health care workers during COVID-19 pandemic. A similar result was found in a cross sectional study conducted among 393 healthcare workers from 5 different districts of Bangladesh in february 2021 revealed that health care workers $88.8 \%$ had a positive attitude regarding PPE. 5
In this study, among the 10 percent of total 138 respondents (total 10 health care workers from Covid isolation ward) showed that less than half of respondents 4 (40\%) had good practice and more than half of respondents $6(60 \%)$ had poor practice regarding the use of PPE (donning and doffing PPE). A contradict result was found in a cross sectional study conducted among Health care among 393 healthcare workers from 5 different districts of Bangladesh in february 2021 which showed that the health care workers (51.7\%) had good practice of using PPE. 5

In this study, it was found that there was significant association between knowledge regarding the use of PPE and training/ continue education $(\mathrm{p}=<0.001)$,

\section{Conclusions}

This study concludes that the periodic training program for newly recruited health care workers and refresher training or continue education for old health care workers to update about the proper use of PPE would enhance the knowledge, attitude and practice of the health care workers. This is an effective strategy to prevent COVID-19 spread among health care workers and patients in the hospital. The study also concludes that the hospitals should follow the standard PPE guidelines by CDC or WHO while donning and doffing the PPE during this COVID-19 pandemic.

\section{Conflict of interest: None}

\section{REFERENCES}

1. Corona virus [Internet].World Health Organization [cited 2020 Nov 15].Available from: https://www. who.int/health-topics/coronavirus\#tab=tab_3

2. Health workers across the country have been infected with coronavirus so far .The Kathmandu Post [Internet]; 2020 July [cited 2020 October 10]. Available from: https://kathmandupost.com/ health/2020/07/03/91-health-workers-across-the-country-have-been-infected-with-coronavirusso-far

3. Rational use of personal protective equipment for coronavirus disease (COVID-19) and considerations during severe shortages [Internet]. Who.int. 2020 December 20 [cited 12 Jan 2021]. Available from: https://www.who.int/publications/i/item/rational-use-of-personal-protective-equipment-for-coronavirus-disease-(covid-19)-and-considerations-during-severe-shortages 
1. Italian doctor dies of coronavirus after reportedly having to treat patients without gloves [Internet]. The Washington post.2020 March 20 [cited 2020 October 10]. Available from: https://www.washingtonpost.com/nation/2020/03/20/coronavirus-italy-doctor-dies/

2. Hossain MA, Rashid MUB, Khan MAS, Sayeed S, Kader MA, Hawlader MDH. Healthcare Workers' Knowledge, Attitude, and Practice Regarding Personal Protective Equipment for the Prevention of COVID-19. J Multidiscip Healthc. 2021 Feb 2 [cited 2021 March 15];14:229-238. Available from: https://pubmed.ncbi.nlm.nih.gov/33564239/ DOI: 10.2147/JMDH.S2937174400 healthcare workers infected in 2 month. Himalayan news service [Internet]; November 28 2020[cited 25 December 2020]. Available from: https://thehimalayantimes.com/nepal/440o-health-workers-infected-in-two-months

3. How to put on and how to remove personal protective equipment (PPE) [Internet].World Health Organization January 24 2015[cited 2020 Nov 15].Available from: https://www.who.int/publications/i/item/WHO-HIS-SDS-2015.1

4. Using Personal protective equipment (PPE) [Internet]. Centers for Disease Control and Prevention August 192020 [cited 25 December 2020]. Available from: https://www.cdc.gov/coronavirus/2019-ncov/hcp/using-ppe.html

5. Jatin V. Badgujar, Gaurav M. Sharma, Nisha R. Relwani, Omprakash S. Rohondia, Tanvi D. Patole, Anjali S. Puntambekar. Knowledge, attitude and practices regarding the use of personal protective equipment during COVID-19 pandemic among health care workers at a tertiary health care center. International Journal of Community Medicine and Public Health. 2021 May[cited 25 May 2021];8(5):2321-2330. Available from: file://C:/Users/ACER/Downloads/7884-31669-1-PB.pdf DOI: https://dx.doi.org/10.18203/2394-6040.ijcmph20211753

6. Hakim SA, Abouelezz NF, EL Okda EM. Use of personal protective devices among health care workers in a teaching hospital in Cairo. Egypt. Egyptian Journal of occupational medicine.2016 July [cited 25 December 2020];40(2):287-300. Available from: https://ejom.journals.ekb.eg/article_846.html DOI: 10.21608/EJOM.2016.846

7. Den Boon S, Vallenas C, Ferri M, Norris SL. Incorporating health workers' perspectives into a WHO guideline on personal protective equipment developed during an Ebola virus disease outbreak.2018 Mar[cited 2020 Nov 15];7:45. Available from: https://www.ncbi.nlm.nih.gov/pmc/articles/ PMC5820616/DOI: 10.12688/f10ooresearch.12922.2

8. Cook TM. Personal protective equipment during the coronavirus disease (COVID) 2019 pandemic - a narrative review. Anaesthesia. 2020 July [cited 2020 Nov 16];75(7):920-927. Available from: https:// pubmed.ncbi.nlm.nih.gov/32246849/DOI: 10.1111/anae.15071

9. Schwartz D, Shapira S, Bar-Dayan Y. Health Care Workers' Knowledge and Confidence in Personal Protective Equipment during the H1N1 Pandemic in Israel. Disaster Medicine and Public Health Preparedness. 2014 April [cited 2020 Nov 16];11:1-8.Available from: https://pubmed.ncbi.nlm.nih. gov/24725982/DOI: 10.1017/dmp.2014.25

10. Ogoina D, Pondei K, Adetunji B, Chima G, Isichei C, Gidado S. Knowledge, attitude and practice of standard precautions of infection control by hospital workers in two tertiary hospitals in Nigeria. J Infect Prev. 2015 Jan [cited 2020 Nov 16];16(1):16-22. Available from: https://www.ncbi.nlm.nih. gov/pmc/articles/PMC5074133/DOI: 10.1177/1757177414558957

11. Shrestha N, Thapa B. Knowledge and Practice on Infection Prevention among Nurses of Bir Hospital, Kathmandu. J Nepal Health Res Counc. 2018 Oct 30[cited 2020 Nov 16];16(3):330-335. Available from: https://pubmed.ncbi.nlm.nih.gov/30455495/ PMID: 30455495.

12. Geberemariyam BS, Donka GM, Wordofa B. Assessment of knowledge and practices of healthcare 
1. workers towards infection prevention and associated factors in healthcare facilities of West Arsi District, Southeast Ethiopia: a facility-based cross-sectional study. Arch Public Health. 2018 Nov 12[cited 2020 Nov 16];76:69. Available from: https://pubmed.ncbi.nlm.nih.gov/30455882/ DOI:10.1186/ s13690-018-0314-0

2. Hasanah, Setiawati, E.P., \& Apriani, L. Althea Med J. Knowledge and Intention to Use Personal Protective Equipment among Health Care Workers to Prevent Tuberculosis. 2016 [cited 2020 Nov 16];3(1):120-5. Available from:http://journal.fk.unpad.ac.id/index.php/amj/article/view/713 DOI: 10.15850/amj.v3n1.713

3. Nhssp.org.np. [cited 2021 Jun 12].Available from: http://www.nhssp.org.np/NHSSP_Archives/ human_resources/HRH_Nepal_profile_august2013.pdf

4. Javaid M, Jamil M, Saddullah H, Haider E, Sajid M, Mahmood A. Knowledge, attitude \& practice regarding use of personal protective equipment (PPE) among dental assistants working at tertiary care hospitals of Multan, Pakistan. PJMHS [Internet].2019 July [cited 2020 October 8];13(3):623-6. Available from : https://www.pjmhsonline.com/2019/july_sep/pdf/623.pdf

5. Shrestha S, Nepal Medical Council Interim Guidance for Infection Prevention and Control When COVID-19 Is Suspected. Nepal Medical Council.2020 April [cited 2020 October 8] 16 p. Available from: https://nmc.org.np/files/4/NMC\%20COVID19\%20Interim\%2oGuideline\%2ofor\%2oprevention\%205\%20April.pdf

6. Paudyal P, Simkhada P, Bruce J. Infection control knowledge, attitude, and practice among Nepalese health care workers. Am J Infect Control. 2008 Oct [cited 2020 October 8]; 36(8):595-7. Available from:https://pubmed.ncbi.nlm.nih.gov/18926315/doi:10.1016/j.ajic.2007.10.026. PMID: 18926315.

7. Rajbhandari AK, Sagtani RA, Thapa B, Adhikari P. Knowledge and attitude regarding infection control and standard precautions among healthcare workers of Rural Nepal.. Birat J Health Sci. 2018 Sep [cited 2020 October];3(2):453-7. Available from:https://www.nepjol.info/index.php/bjhs/article/ view/20944doi: 10.3126/bjhs.v3i2.20944.

8. Reid SM, Farion KJ, Suh KN, Audcent T, Barrowman NJ, Plint AC. Use of personal protective equipment in Canadian pediatric emergency departments. CJEM. 2011 Mar [cited 2020 Nov 2];13(2):71-8. Available from: https://pubmed.ncbi.nlm.nih.gov/21435312/DOI:10.2310/10.2310/8000.2011.110253

9. Fayaz SH, Higuchi M, Hirosawa T, Sarker MA, Djabbarova Z, Hamajima N. Knowledge and practice of universal precautions among health care workers in four national hospitals in Kabul, Afghanistan. J Infect Dev Ctries. 2014 Apr [cited 2020 Nov 2];8(4):535-42. Available from: https://pubmed.ncbi. nlm.nih.gov/24727521/doi: 10.3855/jidc.4143

10. Boon SD, Vallenas C, Ferri M, Norris SL. Incorporating health workers' perspectives into a WHO guideline on personal protective equipment developed during an Ebola virus disease outbreak [Internet]. F100o Research. U.S. National Library of Medicine.2018 Mar [cited 2021Jun12];7(45). Available from: https://www.ncbi.nlm.nih.gov/pmc/articles/PMC5820616/DOI: 10.12688/f10ooresearch.12922.2

11. Coronavirus disease (COVID-19): How is it transmitted? [Internet]. World health organization. 2020 December 13 [cited 25 December 2020]. Available from: https://www.who.int/news-room/q-a-detail/ coronavirus-disease-covid-19-how-is-it-transmitted

12. Tabah A, Ramanan M, Laupland KB, Buetti N, Cortegiani A, Mellinghoff J, Conway Morris A. Personal protective equipment and intensive care unit healthcare worker safety in the COVID-19 era (PPE-SAFE): An international survey. J Crit Care [Internet]. 2020 Oct [cited 2020 December];59:70-75. Available from: https://pubmed.ncbi.nlm.nih.gov/32570052/ DOI:10.1016/j.jcrc.2020.06.005 